\title{
Tetrasomy 21 pter $\rightarrow q 21.2$ in a male infant without typical Down's syndrome dysmorphic features but moderate mental retardation
}

\author{
I Rost, H Fiegler, C Fauth, P Carr, T Bettecken, J Kraus, C Meyer, A Enders, A Wirtz, T Meitinger, \\ N P Carter, M R Speicher
}

J Med Genet 2004;41:e26 (http://www.jmedgenet.com/cgi/content/full/41/3/e26). doi: 10.1136/jmg.2003.01 1833

D own's syndrome is caused by trisomy of chromosome 21. This invariably results in cognitive impairment, hypotonia, and characteristic phenotypic features such as flat facies, upslanting palpebral fissures, and inner epicanthal folds, and variations in digits and the ridge formation on hands and feet. Furthermore, trisomy 21 is a risk factor for congenital heart disease, Hirschsprung's disease, and many other developmental abnormalities. ${ }^{1}$

The physical phenotype of Down's syndrome has often been attributed to an imbalance of the region comprising bands in chromosome region q22.1-q22.3. ${ }^{1}$ However, imbalance of other regions on chromosome 21 may also contribute to the phenotype. A "phenotypic map" established from cell lines from patients with partial trisomy 21 suggested that Down's syndrome is a contiguous gene syndrome. These results argued against a single chromosomal region responsible for most of the Down's syndrome phenotypic features. ${ }^{2}$ However, it still remains unknown how the inheritance of three copies of chromosome 21 produces this broad spectrum of problems and which genes on chromosome 21 play a key role in the various symptoms characterising the syndrome.

Patients with over-representation of defined regions on chromosome 21 may help explain the pathogenetic mechanisms in Down's syndrome. ${ }^{2}$ Patients with partial chromosome 21 imbalance are rare. A large number of partial chromosome 21 trisomies result from unbalanced translocations ${ }^{3}$ and are often accompanied by deletions of other regions in the genome. Such deletions undoubtedly contribute to the phenotypic changes in addition to the partial trisomy 21 .

Particularly rare cases are complete or partial tetrasomy 21 that usually involve no other chromosome material. To our knowledge, complete or partial tetrasomy 21 without mosaicism has been reported in only five liveborn infants. ${ }^{4-8}$ Four of these five infants showed classical dysmorphic signs of Down's syndrome ${ }^{4-68}$ (table 1). In the case described by Cerretini et al, ${ }^{7}$ the child showed only one (brachycephaly) of the ten most discriminating features of Down's syndrome, ${ }^{9}$ suggesting that partial tetrasomy 21 does not consistently produce a Down's syndrome phenotype.

The human chromosome 21 gene expression atlas in the mouse is a new tool that provides a better understanding of gene dosage effects on chromosome 21. ${ }^{10}{ }^{11}$ As many human genes have equivalents in mice, orthologues of confirmed and predicted human chromosome 21 genes were used to study the expression of the corresponding genes in various tissues and at defined stages of development. ${ }^{10}{ }^{11}$ A corroboration of the data in this atlas with clinical data from patients with partial chromosome 21 imbalance may help to elucidate which genes are responsible for certain abnormalities of development and function.

Here, we describe a patient with a marker chromosome derived from chromosome 21 . The phenotype is remarkable

\section{Key points}

- Genetic investigation of patients with a partial chromosome 21 imbalance should help define which genes of chromosome 21 play a key role in the various symptoms of Down's syndrome.

- We present a male infant with an additional marker chromosome derived from chromosome 21. The patient's phenotype was not characteristic of Down's syndrome; however, he had moderate mental retardation, comparable to the cognitive defects usually seen in Down's syndrome patients.

- Fine mapping of the involved region was achieved by array comparative genomic hybridisation on a recently developed $1 \mathrm{Mb}$ large insert clone array.

- This approach allowed us to identify genes in the overrepresented region. We used the recently established human chromosome 21 gene expression atlas in the mouse to correlate the expression pattern with the clinical phenotype.

- We found a compelling correlation between putative expression patterns and the phenotype of the patient. Many genes within the involved region are expressed during the development of the brain. Other genes that are Down's syndrome candidate genes for heart defects, limb abnormalities, or gastrointestinal abnormalities were not present in this region.

- The specific region of chromosome 21 over-represented in this case appears to define genes contributing to mental retardation rather than to the other physical defects typical of Down's syndrome.

as the patient has none of the clear dysmorphic features usually seen in Down's syndrome. However, the child had moderate mental retardation with cognitive defects comparable to those seen in patients with Down's syndrome. Using array comparative genomic hybridisation (CGH) on the recently developed $1 \mathrm{Mb}$ large insert clone array, ${ }^{12}$ we fine mapped the involved chromosome 21 region and confirmed the finding using FISH with BAC clones. We identified the genes within the over-represented chromosome 21 region and correlated the phenotype of our patient with the data from the human chromosome 21 gene expression atlas.

Abbreviation: $\mathrm{CGH}$, comparative genomic hybridisation 


\section{CASE REPORT}

The patient is the second child of healthy, non-consanguineous parents, and was born after a normal pregnancy. At birth, the mother was 33 years old and the father was 40 years old. The birth weight was $3690 \mathrm{~g}$ (50th-75th centile), length $54 \mathrm{~cm}$ (75th-90th centile), and head circumference $34 \mathrm{~cm}$ (10th-25th centile). During the neonatal period, severe hypotonia was noted but no general lethargy. Referral at age of 27 months was mainly for speech retardation. His physical examination did not show clear physical signs associated with Down's syndrome (fig 1). Both length $(85 \mathrm{~cm})$ and weight $(11 \mathrm{~kg})$ lay between the $3 \mathrm{rd}$ and 10th centile, and the head circumference $(47 \mathrm{~cm})$ was below the 3rd centile. The face was round without brachycephaly (fig 1A, B). The palpebral fissures were slightly upslanting. The iris showed patterns resembling Brushfield spots. The ears were of normal size and the mouth was frequently open. The fifth finger appeared to be somewhat shortened (fig 1C). The gap between the first and second toes was slightly increased but not to the extent usually seen in patients with Down's syndrome (fig 1D). The dermatoglyphic features revealed ulnar loops on all fingertips, but no transverse palmar crease. A congenital heart defect was ruled out by an electrocardiogram and ultrasound.

A thorough neurological examination was performed, which revealed developmental retardation in the range of 10-12 months. The developmental quotient, based on the Bayley Scales of Infant Development, was determined to be below 50. The Jackson score for the patient was 5, which is borderline between normal and patients with Down's syndrome. The Rex/Preuss score was -2.49 , thus within the normal range.

In summary, the patient had no definite dysmorphic features; however, he did display a significant developmental delay consistent with the diagnosis of moderate mental retardation (summary in table 1 ).

\section{METHODS}

\section{GTG banding analysis}

Metaphase preparation was performed according to standard protocols.

\section{FISH to determine the chromosomal origin}

The labelling and hybridisation of painting probes was performed according to standard protocols as described previously. ${ }^{13}$

Pools of human ribosomal DNA $11.9 \mathrm{~kb}$ and $19.8 \mathrm{~kb}$ EcoRI fragments ${ }^{14}$ were used for the delineation of rDNA. Probe preparation, labelling, and hybridisation were as described previously. ${ }^{15}{ }^{16}$

\section{Array CGH}

Array CGH was performed on the recently developed human $1 \mathrm{Mb}$ large insert clone array. ${ }^{12}$ This array consists of about 3500 clones selected from the published Golden Path, which are spaced at approximately $1 \mathrm{Mb}$ intervals across the genome. Hybridisation and array evaluation were performed according to previously published protocols. $^{12}$

\section{Confirmation with BAC hybridisations}

We selected six BAC clones to confirm the array CGH results. The map positions of the clones are depicted in fig 2, these clones were: RP11-126N20 (fig 2, no. 2), RP1-270M7 (no. 3), RPl-152M24 (no. 4), RP11-132H24 (no. 13), AP000233 (RP4655M9) (no. 14), and RPl1-266G18 (no. 15). Labelling and hybridisation was performed according to previously published protocols. ${ }^{17}$

\section{Parental origin of the marker chromosome}

Two pairs of primers were selected for microsatellite markers (D21S1256 and D21S1914) from the ABI Prism Linkage Mapping Set-MD 10 (Applied Biosystems). The primers lay within the tetrasomic chromosome content of the marker chromosome.

Using PCR, I $\mu \mathrm{g}$ DNA (100-200 $\mu \mathrm{g} / \mathrm{ml})$ from mother, father, and child was amplified using the aforementioned fluorochrome labelled primer pairs. Conditions of amplification were as specified by the manufacturer except that the reaction volume was $25 \mu \mathrm{l}$ and the number of cycles was reduced to 30. A $1 \mu \mathrm{l}$ aliquot of the PCR product was diluted to $12 \mu \mathrm{l}$ in HiDi Formamide (Applied Biosystems), denatured at $94^{\circ} \mathrm{C}$ for 3 minutes, chilled on ice, and analysed on an ABI 3100 capillary sequencer (Applied Biosystems) in the Genescan mode using procedures as specified by the manufacturer. Evaluation of runs was performed with the Genescan Software (version 2.0; Applied Biosystems).

\section{RESULTS AND DISCUSSION Banding analysis and FISH to determine the chromosomal origin}

The GTG banding analysis revealed an extra marker chromosome, which was bisatellite, in all analysed cells of the patient. Its morphology suggested a derivation from a G group chromosome. The chromosomes of both parents were normal (data not shown).

Two colour experiments with a chromosome 21 painting probe and a rDNA probe demonstrated that the marker was derived from chromosome 21 (fig 3). The marker showed rDNA signals on both ends of the chromosome. Together with the GTG and DAPI banding patterns, it was concluded that this bisatellited dicentric marker could best be described as a psu $\operatorname{dic}(21)$.

Fine mapping of the marker chromosome breakpoint using array CGH and BAC hybridisations

With the exception of chromosome 21 , array CGH revealed balanced ratio profiles for all other chromosomes (data not shown). The array CGH results for chromosome 21 are illustrated in fig 2. The proximal chromosome 21 clones had $\log _{2}$ ratio values of 1 , which corresponds to four copies or a tetrasomy for the respective region. Of special interest was clone RP11-266G18 (no. 15 in fig 2) which showed a $\log _{2}$ ratio value of 0.3 increase above BAC clones with balanced values $\left(\log _{2}\right.$ of 0 ) but lower than the other BAC clones within the tetrasomic region.

For several clones (2-4 and 13-15) we corroborated the array ratio values with $\mathrm{BAC}$ clone hybridisations. With the exception of clone RP11-266G18, hybridisation of all other clones resulted in two signals on the marker chromosome. The distance between these two signals was larger for clones close to the centromere and became narrower as more distal clones were mapped. Clone RP11-266G18 was believed to be breakpoint spanning because its ratio value yielded only one signal on the marker chromosome. This signal was smaller than the signals observed on the two normal chromosomes 21 (fig 2). Thus the breakpoint is within clone 15, within chromosome band 2lq21.2.

The long arm of chromosome 21 has a length of $33.5 \mathrm{Mb}$ and carries 225 genes. ${ }^{18}$ Our fine mapping of the breakpoint revealed that the marker chromosome includes the proximal $12.4 \mathrm{Mb}$ or $37.0 \%$ of the long arm. This region harbours 34 (15.1\%) of the 225 genes on chromosome 21 .

\section{Parental origin of the marker chromosome}

The parental origin of the marker chromosome was determined using several markers (D21S1914, D21S1256). This 
Table 1 Cytogenetic and clinical features of cases with complete and partial tetrasomy 21

\begin{tabular}{|c|c|c|c|c|c|c|}
\hline Case report & Ref. 4 & Ref. 5 & Ref. 6 & Ref. 7 & Ref. 8 & This case \\
\hline $\begin{array}{l}\text { Peripheral blood } \\
\text { lymphocytes }\end{array}$ & $48, X Y,+21,+21$ & $\begin{array}{l}47, X X,+i d i c(21) \\
\text { (q22.1) }\end{array}$ & $\begin{array}{l}47, X Y,+p s u \\
\text { idic(21)(q22.1) }\end{array}$ & $\begin{array}{l}47, X Y,+p s u \operatorname{dic}(21 ; 21) \\
\text { (q22.11;q22.11) }\end{array}$ & $\begin{array}{l}47, X Y,+p s u \\
\text { idic(21)(q22.1) }\end{array}$ & $\begin{array}{l}47, X Y,+p s u \\
\text { idic(21)(q21.1) }\end{array}$ \\
\hline $\begin{array}{l}\text { Parental } \\
\text { chromosomes }\end{array}$ & Normal & $\begin{array}{l}\text { Maternal studies } \\
\text { normal }\end{array}$ & Normal & Normal & Normal & Normal \\
\hline Mother's age & 24 years & 32 years & 33 years & 46 years & 34 years & 33 years \\
\hline Father's age & 36 ears & $\mathrm{NI}$ & 32 years & 52 years & 33 years & 40 years \\
\hline Pregnancy & Spotting/cough & Normal & Bleeding & $\mathrm{NI}$ & $\downarrow$ weight gain & Normal \\
\hline Gestation & 32 weeks & Term & 38 weeks & $\mathrm{NI}$ & 33 weeks & Term (39 weeks) \\
\hline Birth weight (g) & 2020 & 2940 & 3600 & 3300 & 1420 & $3690 \mathrm{~g}$ \\
\hline Age at referral & 4 days & 33 months & 29 months & 9.2 years & 18 month & 27 months \\
\hline Length & $\mathrm{NI}$ & $89.5 \mathrm{~cm}(25 \mathrm{th})$ & $90 \mathrm{~cm}$ (50th) & NL range & $68 \mathrm{~cm}(<3 \mathrm{rd})$ & $85 \mathrm{~cm}$ (3rd-10th) \\
\hline Weight & $\mathrm{NI}$ & $12.0 \mathrm{~kg}$ (10th) & $10.9 \mathrm{~kg}$ (10th) & NL range & $8.88 \mathrm{~kg}(<3 \mathrm{rd})$ & $11 \mathrm{~kg}$ (3rd-10th) \\
\hline Head circumference & $\mathrm{NI}$ & $45.5 \mathrm{~cm}(<3 \mathrm{rd})$ & $45.5 \mathrm{~cm}(<3 \mathrm{rd})$ & NL range & $40.3 \mathrm{~cm}(<3 \mathrm{rd})$ & $47 \mathrm{~cm}(<3 \mathrm{rd})$ \\
\hline Motor development & $\mathrm{NI}$ & Normal & Unable to walk & Retarded & Unable to sit & Retarded \\
\hline Speech & $\mathrm{NI}$ & Single words & & & Babble & Single words \\
\hline Jackson Score & 9 & 10 & 7 & 1 & 12 & 5 \\
\hline Brachycephaly & + & + & + & + & + & - \\
\hline $\begin{array}{l}\text { Upslanted palpebral } \\
\text { fissures }\end{array}$ & + & + & + & - & - & + \\
\hline Epicanthal folds & + & - & - & - & + & - \\
\hline Brushfield spots & $\mathrm{NI}$ & - & + & - & - & $(+)$ \\
\hline Flat nasal bridge & + & - & + & - & + & $(+)$ \\
\hline Open mouth & $\mathrm{NI}$ & + & + & - & + & + \\
\hline Protruding tongue & $\mathrm{NI}$ & + & + & - & + & - \\
\hline Furrowed tongue & $\mathrm{NI}$ & - & - & - & - & - \\
\hline Ears small/low set & + & - & - & - & - & - \\
\hline Short neck & + & + & - & - & + & - \\
\hline Excess nuchal skin & + & - & - & - & + & - \\
\hline $\begin{array}{l}\text { Short and broad } \\
\text { hands }\end{array}$ & $\mathrm{NI}$ & + & - & - & + & - \\
\hline Short fifth finger & $\mathrm{NI}$ & + & - & - & + & $(+)$ \\
\hline $\begin{array}{l}\text { Transverse palmar } \\
\text { crease }\end{array}$ & - & + & - & - & - & - \\
\hline $\begin{array}{l}\text { Gap between 1st } \\
\text { and 2nd toes }\end{array}$ & + & - & - & - & - & $(+)$ \\
\hline $\begin{array}{l}\text { Congenital heart } \\
\text { defect }\end{array}$ & PDA & - & - & - & - & - \\
\hline Muscular hypotonia & + & + & + & $\mathrm{NI}$ & + & + \\
\hline
\end{tabular}

$\mathrm{NI}$, no information; NL, normal; +, symptom present; $(+)$, symptom present with less characteristic features; -, symptom absent.
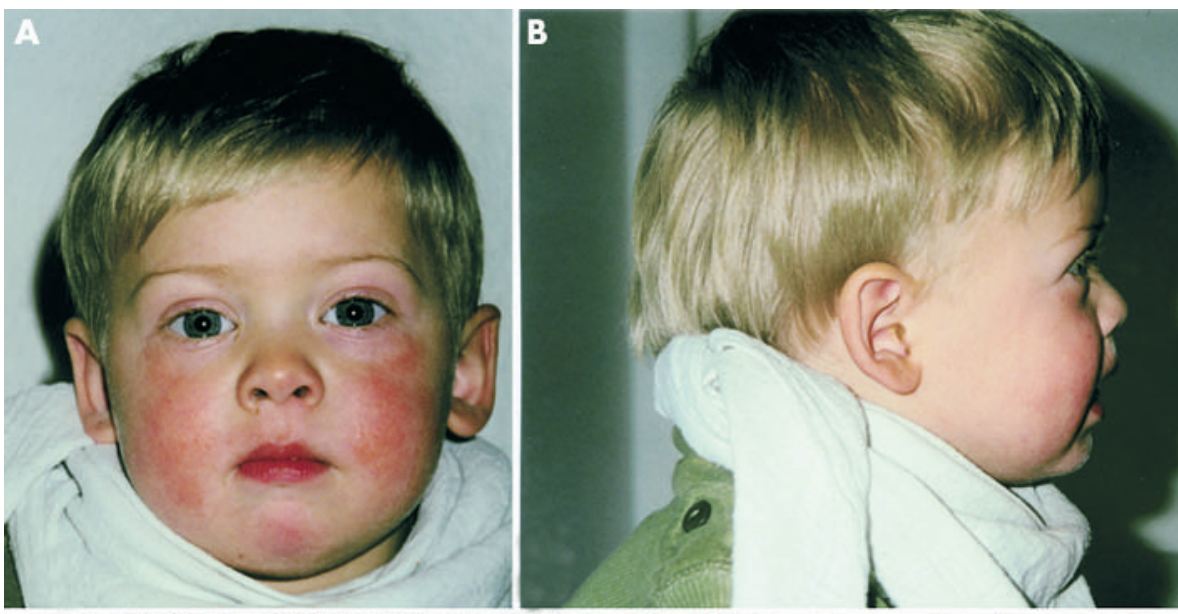

Figure 1 Proband aged 27 months. Face with (A) frontal view, (B) lateral view, (C) hands, and (D) feet.
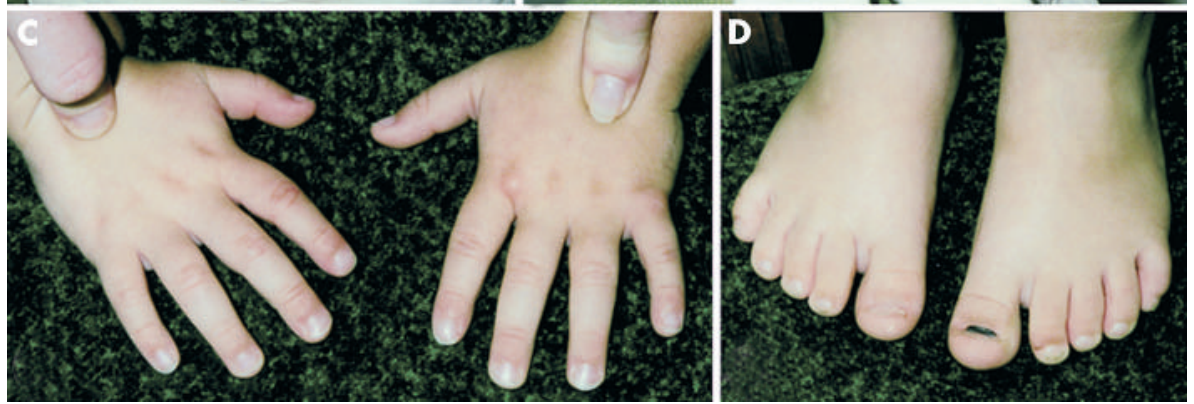


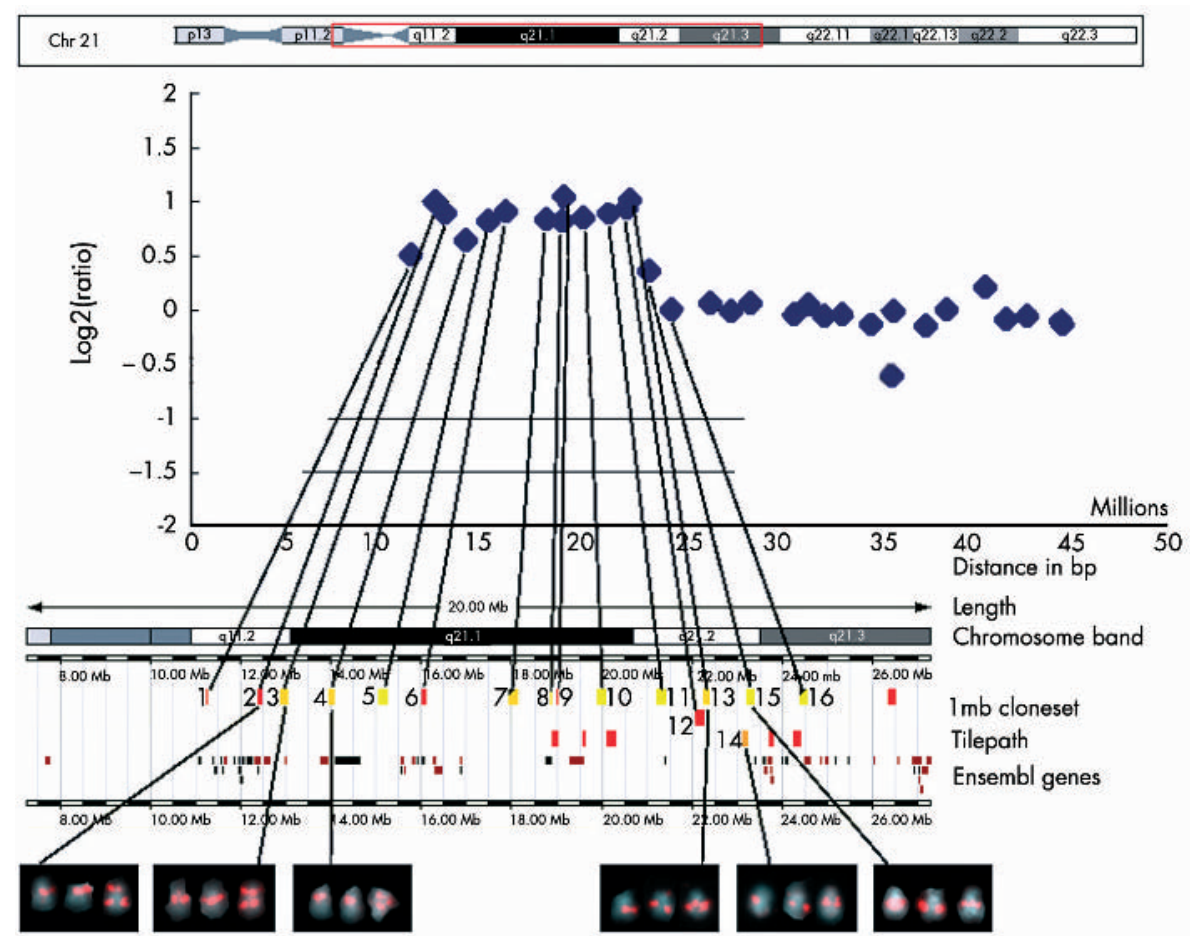

Figure 2 Summary of the array CGH and FISH fine mapping results. The top of the figure shows a diagram of chromosome 21. The segment, which is shown enlarged at the bottom, is encircled in red. The array CGH results are indicated in a coordinate system. The abscissa shows the position of the clones in $\mathrm{Mb}$ according to the draft genomic sequence and the ordinate the mean $\log _{2}$ ratios of the duplicated spots normalised to the median $\log _{2}$ ratio for the genome as described. ${ }^{12}$ For the ratios, $0=$ a balanced ratio, $0.5=$ a trisomy, and $1=$ a tetrasomy. Below the coordinate system is the exact map position of chromosome 21 BAC clones shown (the representation was taken from the Ensembl server release 14.31.1 from June 2, 2003). The top two rows display BAC clones from the $1 \mathrm{Mb}$ clone set. These are the clones, which are present on the array. The third row displays some probes from the tiling path. The most proximal clones were numbered from 1 to 16 as follows: (1) RP1 1-193b6, (2) RP1 1-126N20, (3) RP1-270M7, (4) RP1-152M24, (5) RP1 1-43A6, (6) RP1 1-304D2, (7) RP1 1-49B5, (8) RP1 1-509A1, (9) RP11-50A12, (10) RP11-258A5, (11) RP1 1-25F24, (12) RP11-15H23, (13) RP1 1-132H24, (14) AP000233/RP4-655M9, (15) RP1 1-266G18, and (16) RP1 1-15H6. Illustrated below the probes is the location of the genes. Known Ensembl predicted genes are shown in red, novel Ensembl predicted genes are shown in black. Displayed at the bottom of the figure are FISH images of BAC clones 2-4 and 13-15. In all cases, the two normal chromosomes 21 are shown to the left, the right chromosome is the idic(21q). The proximal chromosome 21 BAC clones in the map are connected to their respective ratio values in the coordinate system or to their respective FISH images.

analysis indicated that the extra chromosome was of maternal origin and not identical with the maternal chromosome 21, which was inherited in toto (data not shown).

\section{Genes within the tetrasomic region and their potential contribution to specific symptoms of Down's syndrome}

Genes within the tetrasomic region were identified using the Ensembl Human Genome Browser (www.ensembl.org; release version 14.13.1; accessed 2 June 2003), which lists all known and novel genes predicted by Ensembl. The 34 genes in the over-represented chromosome 21 region are listed in table 2 . Twenty of these 34 genes are designated as "novel" and no specific function has as yet been assigned to these genes.

The exact effect of the over-representation of the other, "known" genes is difficult to estimate as genes may be active only in some tissues and only at specific stages of embryonic development. In order to check how these genes may have contributed to the patient's phenotype, we used the recently established human chromosome 21 gene expression atlas in the mouse. ${ }^{10}{ }^{11}$ This atlas indicates when and where murine orthologues of human chromosome 21 genes are expressed during development.

The atlas indicated five mouse orthologous genes (SAMSNI, USP25, CXADR, C21orf91/YG-81, and CHODL) with a high expression in the brain, and five genes (TPTE/PTEN2, STCH, NRIP1/RIP140, BTG3, and NCAM2) with a clear identification of the transcript in the brain. All of these genes were within the over-represented chromosome 21 region and may contribute to the cognitive defects of the patient and similarly

Table 2 Genes within the tetrasomic region of chromosome 21

\begin{tabular}{ll}
\hline Chromosome band & Genes \\
\hline p11.2 & TPTE/PTEN2 \\
q11.2 & Novel (12x) \\
& NM_174981 \\
& ABCC13 \\
& STCH \\
& SAMSN1 \\
& NRIP1/RIP140 \\
& Novel (7x) \\
q21.1 & USP25 \\
& CXADR \\
& BTG3 \\
& C2lorf91/YG-81 \\
& CHODL (c21 lorf68/PRED12) \\
& PRSS7 \\
& PPIA \\
& NCAM2 \\
& Novel (1x) \\
q21.2 proximal to & \\
breakpoint & \\
\hline
\end{tabular}

Based on the data in the Ensembl server, these genes were selected. Thirty-four genes are within the tetraploid region.

Genes included in the human chromosome 21 gene expression atlas ${ }^{10}$ are in bold. 


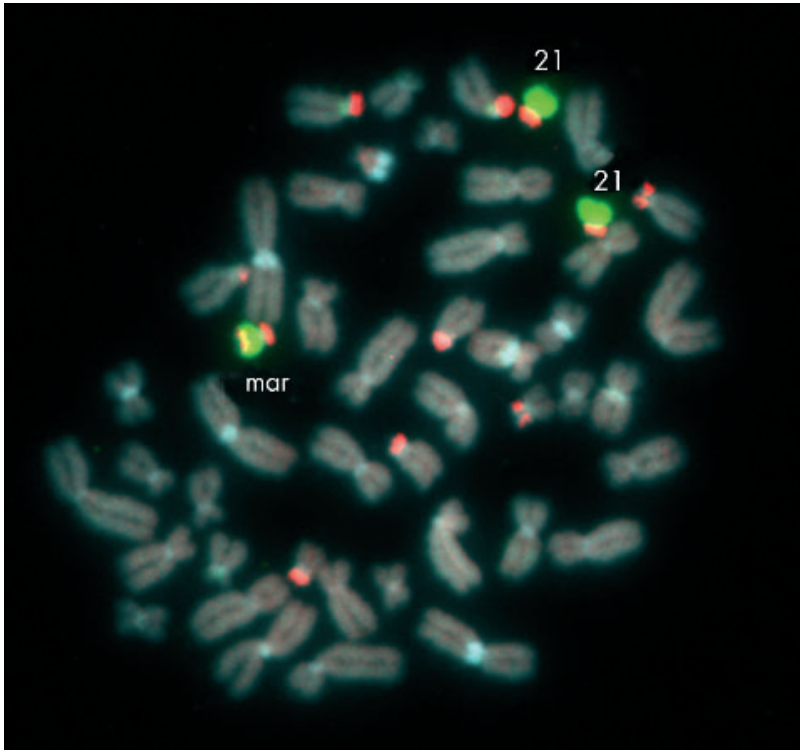

Figure 3 Metaphase spread after hybridisation with a chromosome 21 painting probe (green) and a rDNA probe (red). The chromosome 21 painting probe hybridised to both chromosomes 21 and to the marker chromosome. The rDNA probe results in a red staining of the $p$ arms of all acrocentric chromosomes. Note that there are red signals at either end of the marker chromosome (the overlap of green and red fluorescence results in one yellow signal), indicating that the marker is a dicentric chromosome.

to the cognitive defects in Down's syndrome. In contrast, other genes that have been discussed as potential candidates for the cognitive defects of Down's syndrome, such as DSCAM, SYNJI, TIAMI, PTTGLIP, WRB, COL18A1, COL6AI, and COL6A2, were not within the over-represented chromosomal region. It is therefore unlikely that the cognitive defects in our patient can be attributed to these genes. At the same time, we cannot rule out the possibility that these genes interact with others in the tetrasomic region and are thus indirectly affected.

Our patient may help to narrow down the roles of other genes contributing to Down's syndrome. Trisomy 21, for example, is also associated with specific heart abnormalities at the atrioventricular canal and atrial septum. Candidate genes for these heart defects, according to the chromosome 21 expression atlas, are PWP2H, C21ORF11, PFKL, ADARB1, C21ORF18, KCNJ15, SH3BGR, and KCNE2. ${ }^{10}{ }^{11}$ None of these genes lies within the tetrasomic region and our patient had no heart anomalies.

The gene expression atlas identified genes such as ATP50, CLDN8, CLIC6, ETS2, TFF3, HMGN1, SH3BGR, WRB, and SODI as candidates that may be potentially responsible for gastrointestinal abnormalities, ${ }^{10}$ which are observed in some Down's syndrome patients. None of these genes is located in the over-represented region identified here, which may therefore explain the lack of any gastrointestinal symptoms in this patient.

Other genes, including TIAMI, SNFILK, ERG, and ADAMTSI are associated with abnormalities of the extremities, such as reduced growth of long limb bones or the hypoplastic middle phalanx of the fifth digit. ${ }^{10}$ In our patient, these abnormalities were not observed and none of these genes lies within the tetrasomic chromosome 21 region.

In summary, this case allows a correlation of human chromosome 21 expression patterns with specific phenotypic features and may add to previous reports of genes contributing to mental or physical defects typical of Down's syndrome (reviewed in Roizen \& Patterson ${ }^{19}$ ). In addition, published phenotypes associated with tetrasomy 21 material have described some physical features uncommon in trisomy $21 .^{4-68}$ These phenotypic effects have been attributed to the four copies of chromosome 21 material. This tetrasomy is likely to be more severe than trisomy of the same chromosome segment because of a correspondingly greater imbalance in gene dosage. Similar dosage effects were reported for other tetrasomies, such as $12 p$ or $15 q$. In our patient, the greater gene dosage imbalance had no obvious effect on any dysmorphic features, which makes it unlikely that the overrepresented genes are involved in any of dysmorphic features typically attributed to Down's syndrome. We propose that the genes in this proximal region may contribute to the moderate mental retardation and the cognitive defects of Down's syndrome.

\section{ACKNOWLEDGEMENTS}

We are grateful to the patient's family for their support and collaboration. This work was supported by the Deutsche Forschungsgemeinschaft (Sp 460/4-1) and the Bundesministerium für Bildung und Forschung (NGFN KB P06T5, P06T6).

\section{Authors' affiliations}

I Rost, A Wirtz, Abteilung für Medizinische Genetik der Kinderklinik, Ludwig Maximilians Universität München, Goethestr. 29, D-80336 München, Germany

H Fiegler, P Carr, N P Carter, The Wellcome Trust Sanger Institute, Wellcome Trust Genome Campus, Hinxton, Cambridge CB10 1SA, UK C Fauth, T Bettecken, J Kraus, C Meyer, T Meitinger, M R Speicher, Institut für Humangenetik, Technische Universität München, Trogerstr. 32, D-81675 München, Germany, and GSF-Forschungszentrum für Umwelt und Gesundheit, D-85764 Neuherberg, Germany Angelika Enders, Zentrum für Entwicklungsneurologie und Frühförderung im Dr. von Haunerschen Kinderspital, Ludwig Maximilians Universität München, Lindwurmstr. 4, D-80337 München, Germany

Christine Fauth, Universität Innsbruck, Institut für Med. Biologie und Humangenetik, Schoepfstr. 41, A-6020 Innsbruck, Austria

Correspondence to: $\operatorname{Dr}$ M R Speicher, Institut für Humangenetik, TU München, Trogerstr. 32, D-81675 München, Germany;

speicher@humangenetik.med.tu-muenchen.de

Received 2 September 2003

Accepted 22 September 2003

\section{REFERENCES}

1 Epstein CJ, In: Scriver CR, Beaudet AL, Sly WS, Valle D, eds. The metabolic and molecular basis of inherited disease, 8th edn. New York: McGraw Hill, 2001:1223-56.

2 Korenberg JR, Chen XN, Schipper R, Sun Z, Gonsky R, Gerwehr S, Carpenter N, Daumer C, Dignan P, Disteche C, Graham JM Jr, Hudgins L, McGillivray B, Miyazaki K, Ogasawara N, Park JP, Pagon R, Pueschel S, Sack G, Say B, Schuffenhauer S, Soukup S, Yamanaka T. Down syndrome phenotypes: the consequences of chromosomal imbalance. Proc Natl Acad Sci USA 1994;91:4997-5001.

3 Valero R, Marfany G, Gil-Benso R, Ibanez MA, Lopez-Pajares I, Prieto F, Rullan G, Sarret E, Gonzalez-Duarte R. Molecular characterisation of partial chromosome 21 aneuploidies by fluorescent PCR. J Med Genet 1999;36:694-9.

4 Jabs EW, Stamberg J, Leonard CO. Tetrasomy 21 in an infant with Down syndrome and congenital leukemia. Am J Med Genet 1982;12:91-5.

5 Daumer-Haas C, Schuffenhaver S, Walther JU, Schipper RD, Porstmann T, Korenberg JR. Tetrasomy 21 pter $\rightarrow$ q22.1 and Down syndrome: molecular definition of the region Am J Med Genet 1994;53:359-65.

6 Gutierrez-Angulo M, Ramos AL, Davalos N, Sanchez-Corona J, Rivera H. An extra idic(21)(q22.1) in a child with some features of Down's syndrome. Clin Genet 1999;55:203-6.

7 Cerretini R, Luccerini V, Stivel M, Banares V, Aranda I, Alba L, Pivetta O, Slavutsky I. Tetrasomy 21 pter-q22.11: molecular, cytogenetic, and clinical findings Clin Genet 1999;55:283-6.

8 Slavotinek AM, Chen XN, Jackson A, Gaunt L, Campbell A, Clayton-Smith J, Korenberg JR. Partial tetrasomy 21 in a male infant. J Med Genet 2000;37:e30

9 Jackson JF, North ER 3rd, Thomas JG. Clinical diagnosis of Down's syndrome. Clin Genet 1976;9:483-7.

10 Reymond A, Marigo V, Yaylaoglu MB, Leoni A, Ucla C, Scamuffa N, Caccioppoli C, Dermitzakis ET, Lyle R, Banfi S, Eichele G, Antonarakis SE, 
Ballabio A. Human chromosome 21 gene expression atlas in the mouse. Nature 2002;420:582-6.

11 Gitton Y, Dahmane N, Baik S, Ruiz i Altaba A, Neidhardt L, Scholze M, Herrmann BG, Kahlem P, Benkahla A, Schrinner S, Yildirimman R, Herwig R, Lehrach $\mathrm{H}$, Yaspo ML. A gene expression map of human chromosome 21 orthologues in the mouse. Nature 2002;420:586-90.

12 Fiegler H, Carr P, Douglas EJ, Burford DC, Scott CE, Hunt S, Smith J, Vetrie D, Gorman P, Tomlinson IP, Carter NP. DNA microarrays for comparative genomic hybridization based on DOP-PCR amplification of BAC and PAC clones. Genes Chrom Cancer 2003:36:361-74

13 Uhrig S, Schuffenhauer S, Fauth C, Wirtz A, Daumer-Haas C, Apacik C, Cohen M, Muller-Navia J, Cremer T, Murken J, Speicher MR. Multiplex-FISH for pre- and postnatal diagnostic applications. Am J Hum Genet 1999:65:448-62.

14 Labella T, Schlessinger D. Complete human rDNA repeat units isolated in yeast artificial chromosomes. Genomics 1989;5:752-60.

15 Grabowski M, Fauth C, Wirtz A, Speicher MR. Breakpoint within the nucleolus organizer region resulting in a reciprocal translocation $\dagger(4 ; 14)(q 21 ; p 12)$. Am J Med Genet 2000;92:264-8.
16 Langer S, Fauth C, Rocchi M, Murken J, Speicher MR. AcroM fluorescent in situ hybridization analyses of marker chromosomes. Hum Genet 2001;109:152-8.

17 Kraus J, Lederer G, Keri C, Seidel H, Rost I, Wirtz A, Fauth C, Speicher MR. A familial unbalanced subtelomeric translocation resulting in monosomy 6q27 $\rightarrow$ qter. J Med Genet 2003;40:e48.

18 Hattori M, Fujiyama A, Taylor TD, Watanabe H, Yada T, Park HS, Toyoda A, Ishii K, Totoki Y, Choi DK, Groner Y, Soeda E, Ohki M, Takagi T, Sakaki Y, Taudien S, Blechschmidt K, Polley A, Menzel U, Delabar J, Kumpf K,

Lehmann R, Patterson D, Reichwald K, Rump A, Schillhabel M, Schudy A,

Zimmermann W, Rosenthal A, Kudoh J, Schibuya K, Kawasaki K, Asakawa S, Shintani A, Sasaki T, Nagamine K, Mitsuyama S, Antonarakis SE, Minoshima S, Shimizu N, Nordsiek G, Hornischer K, Brant P, Scharfe M,

Schon O, Desario A, Reichelt J, Kaver G, Blocker H, Ramser J, Beck A, Klages S, Hennig S, Riesselmann L, Dagand E, Haaf T, Wehrmeyer S, Borzym K, Gardiner K, Nizetic D, Francis F, Lehrach H, Reinhardt R, Yaspo ML. The DNA sequence of human chromosome 21. Nature 2000;405:311-19.

19 Roizen NJ, Patterson D. Down's syndrome. Lancet 2003;361:1281-9. 